\title{
Pressure Ulcer Stages among Bed-Ridden Patients in Ahmadu Bello University Teaching Hospital (ABUTH), Zaria- Nigeria
}

\author{
*Ladan Muhammad Awwal, GarbaSalehNgaski, SaniDalhatu Khalid, Sani \\ Muhammad Hadiza, Muhammad Awwal Farouk \\ (Department of Nursing Sciences, Faculty of Medicine, Ahamdu Bello University, Zaria-Nigeria)
}

\begin{abstract}
This study was carried out to assesspressure ulcer stages among bed-ridden patients in Medical, Neurosurgical and Orthopaedic wards inAhmadu Bello University Teaching Hospital (ABUTH) Shika-Zaria. The main aim of this study is to determine the prevalence as well as the stages of pressure ulcers among bedridden patients and to assess the Nurses' awareness and application of the awareness in the stage-based treatment of pressure ulcer in ABUTH. The descriptive survey design was adopted and data was collected with the help of questionnaire and observation checklist. A convenient sampling method was used among the bedridden patients and a single-stage cluster method was used among the nurses in the three wards. The study sample consisted of 51 Nurses whom answered a pre-established Questionnaire and 129 bed-ridden patients whom were observed using Observational Checklist. The Major Findings were as follows: the cumulative point prevalence of Pressure ulcer was noted to be $18.6 \%$ which is significantly high; Pressure ulcer stages were observed to be highest for Stages III (37.5\%), and Stage IV (33.3\%) which are the advanced stages, and then low in Stage II (20.8\%) and Stage I (8.3\%). Furthermore, 96\% of Nurses were observed to be aware of pressure ulcer stages and $82 \%$ apply their awareness in the stage-based treatment of pressure ulcer. In conclusion, there was a high prevalence of pressure ulcer among bed-ridden patients majority of which were the advanced stage of the condition. Therefore it is recommended that, use of a risk assessment tool such as theBraden Scale on admission will identify if the client has pressure ulcer or not, and if they do, at which stage, health care professionals should be more informed about secondary conditions that may occur in the course of patient's stay in the hospital rather than emphasis only on primary condition that warranted admission, and patient's relatives should be informed about the risk factors for the development of pressure ulcers since they are also fully involved in the care.
\end{abstract}

Keywords: Pressure ulcer, staging, risk factors

\section{*CORRESPONDENCE AUTHOR}

\section{Introduction}

Pressure ulcers, also known as pressure sores, decubitus ulcers and bed sores, are areas of localized damage to the skin and underlying tissue (Allman, 1997). Pressure ulcers are a common and serious healthcare problem where immobile, old and care-dependent patients are concerned. The National Pressure Ulcer Advisory Panel (NPUAP) and the European pressure ulcer advisory panel (EPUAP) described pressure ulcer as "localized injury to the skin and/or underlying tissue usually over a bony prominence, as a result of pressure, or pressure in combination with shear and/or friction" (European pressure ulcer advisory panel and National pressure ulcer advisory panel, 2009). According to John (2006), a pressure ulcer is an injury to the skin as a result of constant pressure due to impaired mobility. If the conditions leading to the pressure sore are not rapidly corrected, the localized skin damage will spread to deeper tissue layers affecting muscle, tendon, and bone.

Numerous studies have been carried out in different parts of the world including North America, Europe, Australia and Africa involving annual surveys conducted on a nationwide basis (Lepisto et al. 2001, Pearson et al. 2000, Thoroddsen 1999, Scott and Newens 1999 and Barczak et al. 1997).Ikechukwu et al. (2012) studied the prevalence rate of hospital acquired ulcers in National Orthopaedic Hospital, Enugu, Nigeria and the finding was $51.6 \%$, which was to have enormously increased compared to previous studies in other parts of the world such as Perneger et al. (1998) which was $10.3 \%$ andGunninberg and Stotts (2008) which was $22.9 \%$. Therefore pressure ulcer has accounted for a serious clinical and economic problem for a resource constrained public hospital system both in Nigeria and perhaps worldwide.

\section{Statement ofthe problem}

Today, much advancements at preventing Pressure ulcers has been documented in the developed nations with the advent of sophisticated equipments such as alternating pressure mattresses/overlays, air fluid beds, low-air-loss beds and devices such as water-filled mattresses, air filled mat-tresses and gel-filled mattresses/overlays among others (Adejumo and Ingwu, 2010). Despite these innovative concepts and 
technology, Pressure ulcers still remains recalcitrant and prevalent among hospitalized and high dependent patients (Chacon et al., 2010; Gunningberg and Stotts, 2008 and Grey et al., 2006). A developing nation like Nigeria seems disadvantaged in combating the challenge of Pressure ulcers due to lack of facilities and trained personnel (Adejumo and Ingwu, 2010).

Episodes of Pressure ulcers are common phenomenon in the Nigerian clinic settings (Ikechukwu et al., 2012) with Ahmadu Bello University Teaching Hospital (ABUTH) inclusive although, there is a dearth of empirical data (Ikechukwu et al., 2012) on their prevalence and the various stages of the ulcers suffered by patients in Nigeria.

\section{Aimand Objectivesof the Study}

The main aim of the study is to assess the pressure ulcer stages among bedridden patients in Medical, Neurosurgical and Orthopaedic wards, Ahmadu Bello University Teaching Hospital (ABUTH).

The specific objectives are:

1. To determine the number of bedridden patients with pressure ulcer in Medical, Neurosurgical and Orthopaedic wards, ABUTH

2. To identify the stages of pressure ulcers among bedridden patients with the condition in medical, neurosurgical and orthopaedic wards, ABUTH.

3. To determine the nurses awareness and its applicationon stage-based treatment of pressure ulcer in medical, neurosurgical and orthopaedic wards, ABUTH.

\section{Significance of the Study}

This study will provide nurses and the management of Ahmadu Bello University Teaching Hospital (ABUTH) with the necessary awareness about the cases and severity of pressure ulcers seen among bed-redden patients as well as the efficiency of the care given by the care providers. By this, the management will be able to reestablish the importance of improving pressure ulcer risk assessment and prevention through the implementation of guideline recommendations and new treatment and prevention protocols of pressure ulcer as an addition to the basic health care practice that is commonly provided for the bedridden patients and others at risk for pressure ulcer development.

\section{Prevalence of pressure ulcer}

\section{Literature Review}

According to the Agency for Healthcare Research and Quality (AHRQ), the number of hospital patients who develop pressure sores has increased by 63\% since 1996(Rosenfeld Law Offices,2012).The National Pressure Ulcer Advisory Panel (NPUAP) says the incidence ranges from 0.4 percent to 38 percent in hospitals, from 2.2 percent to 23.9 percent in skilled nursing facilities, and from 0 percent to 17 percent for home health agencies (Cuddigan,Berlowitz and, Ayello,2001). There is ample evidence that the majority of pressure ulcers occur relatively early in the admissions process. For patients in the hospital, they can occur within the first 2 weeks (Langemo, et.al, 1989). With the increased acuity of elderly patients admitted and decreased lengths of stay in hospital, new data suggest that 15 percent of elderly patients will develop pressure ulcers within the first week of hospitalization (Lyder, et al, 2001). For those elderly residents admitted to longterm care, pressure ulcers are most likely to develop within the first 4 weeks of admission (Bergstrom and Braden, 1992).

Eberhardt, et.al.(2004) estimate an overall prevalence of 9.2\% among institutionalized patients, based on estimated local prevalence of $5 \%$ to $10 \%$ in hospitals,about $30 \%$ in geriatric clinics and homes for the elderly andabout $20 \%$ in nursing-dependent patients being cared for at home.

According to Tillmann(2010), the prevalence of high-grade decubitus ulcers (grades 3 and 4) is as high as $3 \%$, and may reach $4 \%$ among elderly persons receiving nursing care in health institutions. There has been no significant decline in the prevalence of decubitus ulcers over the last 10 years, as a study from Hamburg has shown (Tillmann, 2010). Although 70 percent of ulcers occur in persons older than 65 years, (Whittington,2000) younger patients with neurologic impairment or severe illness are also susceptible. Prevalence rates range from 4.7 to 32.1 percent in hospital settings (Kaltenthaler et.al, 2001) and from 8.5 to 22 percent in nursing homes (Coleman, Martau and Kramer, 2002).The prevalence of advanced pressure ulcers is high in older persons, peaking in those between age 70 and 80 years. The statistics show that $70 \%$ of pressure ulcers occur in individuals over the age of 70 years old (Gray and Harding, 2006). Also according to Dharmarajan and Ugalino (2002), Whereas the general incidence of pressure ulcers in hospitals varies, ranging from $1.2 \%$ to nearly $3 \%$, it may be as high as $50 \%$ in acute care geriatric units and is associated with a high mortality rate (Allman, 1997).Moreover, the morbidity associated with the development of pressure ulcers increases the length of stay and resultant expense of hospitalization, hardly affordable consequences in today's era of health care. Specifically, the duration of hospitalization increases up to 5-fold when patients develop pressure ulcers, with 
the mean hospital cost nearly doubling (Allman, 1997).Pressure ulcers have been reported in most patient care environments; accurately ascertaining the prevalence of pressure ulcers in the operating room has been difficult. However, the results may have included existing pressure ulcers (prevalence) as well as newly acquired ulcers (incidence).

Pressure ulcers also increase length of stay by an (average) additional 3.5 to 5 days (Schultz et al, 2003; Sharon, 1999). According to Dharmarajan and Ugalino (2002), pressure ulcers can develop at any site, they occur more frequently over bony prominences, and also the patient's position and degree of immobility can influence the site of involvement. The most common locations are the sacrum, coccyx, and heels (when persons are in a supine position); the hips and ankles (when persons are lying on their sides); and the buttocks (when persons are seated). Less commonly involved are the earlobes, occiput, chin, elbow, scapula, and knee. The lower half of the body accounts for 95\% of pressure ulcers (Thomas, 1997 and Smith 1996).

\section{Risk factors for pressure ulcers}

Dharmarajan and Ugalino, (2002) mentioned that the risk factors for the development pressure ulcers have been grouped by several writers as intrinsic (such as: aging skin, patients with cerebrovascular disease, Parkinson's disease, advanced dementia, contractures, and most commonly orthopaedic injuries, conditions that restrict mobility, such as diabetic neuropathy and spinal cord injuries)and extrinsic factors (such as pressure, friction, shearing, and moisture).

\section{Pressure ulcer staging}

Pressure ulcer stages: are distinct phases or periods in the course of a localized damage to the skin and underlying tissue.The National Pressure Ulcer Advisory Panel (NPUAP), 2007 updated the pressure ulcer staging system as follows:

\section{Suspected Deep Tissue Injury:}

Purple or maroon localized area of discolored intact skin or blood-filled blister due to damage of underlying soft tissue from pressure and/or shear. The area may be preceded by tissue that is painful, firm, mushy, boggy, warmer or cooler as compared to adjacent tissue.

\section{Stage I:}

Intact skin with non-blanchable redness of a localized area usually over a bony prominence. Darkly pigmented skin may not have visible blanching; its color may differ from the surrounding area.

\section{Stage II:}

Partial thickness loss of dermis presenting as a shallow open ulcer with a red pink wound bed, without slough. This may also present as an intact or open/ruptured serum-filled blister.

Stage III:

Full thickness tissue loss. Subcutaneous fat may be visible but bone, tendon or muscle are not exposed. Slough may be present but does not obscure the depth of tissue loss.

Stage IV:

Full thickness tissue loss with exposed bone, tendon or muscle. Slough or eschar may be present on some parts of the wound bed. Often include undermining and tunneling.

Unstageable:

Full thickness tissue loss in which the base of the ulcer is covered by slough (yellow, tan, gray, green or brown) and/or eschar (tan, brown or black) in the wound bed.

\section{General Treatmentof Pressureulcer}

Many aspects of managing pressure ulcers are similar to prevention (mechanical loading, support surfaces, and nutrition). Clearly, the health care team has to address the underlying causes (intrinsic and extrinsic) or the pressure ulcer will not close. In 1994, The Agency for Healthcare Research and Quality (AHRQ) published clinical practice guidelines on treating pressure ulcers, Rockville, (1994). The document identified specific indices (e.g., wound assessment, managing tissue load, ulcer care, managing bacterial colonization/infection, etc.). The treatment involves Cleansing, Assessment and Staging, Debridement, Infection control, Wound intervention, Nutrition, Pain Management, and Adjunctive Therapies.

\section{Study Design}

\section{Methodology}

A descriptive survey design was used to assess pressure ulcer stages among bed-ridden patients in medical, orthopaedic and neurosurgical wards and also the Nurses' awareness and knowledge regarding stagebased treatment of pressure ulcer using frequency distribution table method. According to walker (2005), a descriptive design describes what exist, as well as determines the importance or significance and the frequency 
with which something occurs. This method involves data collection from bedridden patients with the use of observational checklist and from nurses in these wards with the use of self-administered questionnaires.

\section{Location for the Study}

The Ahmadu Bello University Teaching Hospital (ABUTH) is the oldest and largest tertiary health institution in northern Nigeria. It was initially located in a temporary site in Tudun-Wada Zaria but the new site was commissioned on the $11^{\text {th }}$ November 2005 by President OlusegunObasanjo. Clinics and departments in ABUTH include, General Outpatient services, pediatrics, surgery, chemical pathology, Immunology and medical microbiology, orthopedics, surgery, clinical pharmacology, pharmaceutical sciences, maxillofacial surgery, anesthesia, intensive care unit, public health disease control, radiology, ophthalmology, psychiatry, obstetrics and gynecology, medicine, haematology, histopathology, radiotherapy and oncology. Trainings offered by ABUTH include medical undergraduate, residency (postgraduate medical training), general nursing, community health officers, post-basic (specialist) nursing and bio-medical engineering.

The specific areas of the study are medical, orthopaedic and neurosurgical wards. There are male and female wards,male and female orthopaedic wardsas well as the male, female and paediatricneurosurgical wards.

\section{Study Population}

The population of study comprise of all the bedridden patients in medical, neurosurgical and orthopaedic wards as well as the nurses currently in these wards. The overall total number of patients in these wards was 129 while the Nurses that worked in these wards were 72.

\section{Sample size and Sampling techniques}

For the bed-ridden patients, a convenient sampling technique was used and a total of 129 bed-ridden patients from the three wards were observed for the study.

However, for the Nurse respondents, a single-stage cluster sampling technique was used, whereby each of the three wards (male and female) were built into single clusters and from there, representations were made. A sample size of 60 was used which represents $83.3 \%$ of the population of the Nurses in the wards.

\section{Data Collection}

The instruments used for data collectionwere observational checklist and self- administered questionnaire. The observational checklist was based on the first two objectives which include assessing the presence of pressure ulcer and the stage of the ulcer if present. The questionnaire was based on the content of the last objective which is assessing the awareness and knowledge of nurses regarding stage-based treatment of pressure ulcer.

\section{Results and Discussion}

Descriptive statisticswas employed to summarize the data of the study sample. The demographic data were presented using frequency tables and percentages. Furthermore, data collected on the pressure ulcer cases, stages of the ulcer as well as the nurses' awareness and attitude to pressure ulcer treatment were also presented using frequency tables and percentages.

The result of the study revealed that the point prevalence of pressure ulcers among bed-ridden patients in the study wards was $18.6 \%$ within the year2012. Previous studies similar findings.For instance, the National Pressure Ulcer Advisory Panel (NPUAP) stated that the incidence ranges from 0.4 percent to 38 percent in hospitals, from 2.2 percent to 23.9 percent in skilled nursing facilities, and from 0 percent to 17 percent for home health agencies (Cuddigan, Berlowitz andAyello, 2001). Furthermore, Kaltenthaler et.al, (2001) observed in their study that the Prevalence rates range from 4.7 to $32.1 \%$ in hospital settings.

From this study, results showed that majority of bed-ridden patients with pressure ulcer were male $(91.7 \%)$ and only $8.3 \%$ were female. This showed similarity with results from other studies, Lahmann et.al (2005) found that in a Nursing homes health survey, male had a higher prevalence of pressure ulcer $(13 \%)$ than female $(10 \%)$. This could be because majority of the patients were males.

This study also showed that the majority of bed-ridden patients who had pressure ulcer were the elderly patients above 65years (37.5\%) and those in the age range of 51-57 years (25\%). In similar studies, Whittington (2000) discovered in his study that $70 \%$ of ulcers occur in persons older than 65 years, whereas younger patients with neurologic impairment or severe illnesses are also susceptible. This could also be due to the fact that majority of the patients observed for this study were above 45 years old.

Findings also indicated that the longer the duration of stay in the hospital, the higher the occurrence of pressure ulcer among bed-ridden patients, with the following results: less than 3 weeks: 8.3\%; within 3-6 weeks: 37.5\% and above 6 weeks: $54.2 \%$. Other studies have showed similar findings such as that ofDharmarajan\&Ugalino (2002) that identified a direct proportional relationship between length of hospital stay and development of 
pressure ulcer. This could also stem from the fact that more emphasis is placed on the primary condition that warranted the patient's admission rather than resultant secondary ailments.

Result from this study showed that majority of bed-ridden patients with pressure ulcers had them in the buttocks and sacrum 50\% and 33.3\% respectively, and this conforms with findings from previous studies for example, it has been observed that the lower half of the body accounts for 95\% of pressure ulcers(Thomas, 1997 and Smith, 1996). Similarly, Dharmarajan and Ugalino (2002) mentioned that the most common locations of pressure ulcer are the buttocks, sacrum, coccyx, and heels (when persons are in a supine position); the hips and ankles (when persons are lying on their sides); and the buttocks (when persons are seated). Less commonly involved are the earlobes, occiput, chin, elbow, scapula, and knee. Reasons for this observation may be directly related to the patient's lying position.

Results from this study revealed that Stage III and Stage IV (advance stage) pressure ulcer occur as the common form of ulcers that bed-ridden patients in the studied wards developed with frequencies as $37.5 \%$ and $33.3 \%$ respectively. Stage I pressure ulcer had the least occurrence (8.3\%). This result appeared to be in contrast with results from studies conducted in developed countries. The National Center for Health Statistics of the Center for Disease Prevention and Control in United State conducted a National Health Survey in 2004 and it was observed that stage II had the highest prevalence forming $45.5 \%$, this was followed by Stage I which formed $27.3 \%$ of the total pressure ulcer cases and the least were Stages III and IV forming 9.1\% and $18.2 \%$ respectively (Eunice and Christine, 2004). Similarly, in a study conducted by Lahmann et.al (2005) on the prevalence of pressure ulcer in Hospitals in Germany, it was discovered that in 2002, the overall prevalence of pressure ulcer including Stage I was $11.1 \%$ whereas that of prevalence of pressure ulcer excluding Stage I was 4.7\%.Thismight be due to the fact that somehealth professionals managing the patients especially in the developing countries like Nigeria weremainly concerned with only the primary cause of hospital admission rather than on prevention of hospital based or care based secondary conditions. The ulcer is then only noticed at latter stages when it becomes offensive or when the patients or their relations complain.

Moreover, findings also showed that almost all the Nurses that participated in the study regardless of their ranks and years of experience were aware of pressure ulcer stages (96\%) and that they had good knowledge about treatment of stages of pressure ulcer with mean frequency of $82 \%$. This showed similarity to the findings of Mike (2008) among Nurses in New Zealand hospitals. It was seen that no difference in knowledge level was found related to nurses' experience, qualifications, or seniority. However, this has not helped in the early recognition of the ulcer stages among the bed-ridden patients.

\section{Conclusion}

The study showed that less than three quarter of the bed-ridden patients in the study wards had pressure ulcers while more than two third of the pressure ulcer were the advanced stages (Stage III and IV).

Findings also showed that more than three quarter of the Nurses in the study wards had good awareness about pressure ulcer stages and good knowledge regarding stage-based treatment of pressure ulcer but this knowledge has not benefitted the clients as majority of them have advanced stages of the pressure ulcer.

Finally, the results provided significant information about the prevalence and stages of pressure ulcer among bedridden patients as well as Nurses awareness and knowledge of pressure ulcer stage treatment in medical, orthopaedic and neurosurgical wards of Ahmadu Bello University Teaching Hospital, Shika.

\section{Recommendations}

Based on the findings of this study, it is recommended that the Management of Ahmadu Bello University Teaching Hospital should develop a strong emphasis on the prevention of hospital acquired pressure ulcers with commitment from all levels of the organization. This can be achieved through the followings:

1. Use of a risk assessment tool such as theBraden Scale on admission. This will identify if the client has pressure ulcer or not, and if they do, at which stage.

2. Health care professionals should be more informed about secondary conditions that may occur in the course of patient's stay in the hospital rather than emphasis only on primary condition that warranted admission.

3. Patient's relatives should be informed about the risk factors for the development of pressure ulcers since they are also fully involved in the care.

\section{Reference}

[1]. AdejumoP.O and Ingwu J.A (2010).Nurses' use of water-filled gloves in preventing heel pressure ulcer in the University College Hospital, Ibadan, Nigeria, International Wound Journal, 7: 472-479. Available at: http://www.academicjournals.org/JPHE. Accessed on 18th July, 2012.

[2]. Allman,R.M (1997) Pressure ulcer prevalence, incidence, risk factors, and impact, Clinical Geriatrics and Medicine, 13(3): 421 436.

[3]. Ayello E.A and Braden B. (2002).How and why to do pressure ulcer risk assessment, Advnced Skin Wound Care; 15:125-31

[4]. Bansal, C, Scott, R. Stewart, D \&Cockerell, C, J(2005): Decubitus ulcers: A review of the literature. International Journal of Dermatology; 44: 805-810 Available at http//: www.pupps3/pressureulcerprevention.org/pdf Accessed on 18 th July, 2012. 
[5]. Bergin S.M, and Wraight, P (2006): Silver based wound dressings and topical agents for treating diabetic foot ulcers. Cochrane Database System Revised.;1:CD005082.

[6]. Bennett,R.G (2000): The increasing medical malpractice risk related to pressure ulcers in the United States. Journal of American Geriatrics Society; $48: 73-81$.

[7]. Bliss, M.R and Thomas, J.M (1993): A basis for future action: applying clinical findings of trials on pressure-relieving supports to practice: kinetic treatment table versus "normal" bed with two-hourly turning, Professional Nurse;8:726,728,730.

[8]. Bolton L,McNees P, van Rijswijk L, de Leon J, Lyder C, Kobza L, et al. (2004) Wound healing outcomes using standardized assessment and care in clinical practice. Journal of Wound Ostomyand Continence Nursing, 31(2):65-71.

[9]. Smeltzer O'Connell S.C, Bare B.G., \& Hinkle J.L., (2012), Brunner and Suddarth: A textbook of medical surgical nursing $12^{\text {th }}$ ed. Lippincotts and willikins. USA. http:/www.buymedicals.com/MedicalInfo/2-urine.asp. Accessed on 25 th February, 2012.

[10]. Chernoff RS, Milton KY, Lipschitz DA (1990). The effect of a very high-protein liquid formula on decubitus ulcer healing in long term tube-fed institutionalized patients. Journal of American Geriatric Social;90:A-130.

[11]. Dharmarajan TS, Ugalino JT (2002) Clinical Review Article: Pressure Ulcers: Clinical Features and Management.pp 64-71. Available at:http//:www.turner-white.com/report/gfvc/pdf.Accessed on 18th July 2012.

[12]. European Pressure Ulcer Advisory Panel and National Pressure Ulcer Advisory Panel (2009). Treatment of pressure ulcers: Quick Reference Guide. Washington DC: National Pressure Ulcer Advisory Panel. Available at: http://www.npuap.org/html. Viewed on the 18 th of July, 2012

[13]. Falanga V., (2002). Wound bed preparation and the role of enzymes: a case for multiple actions of therapeutic agents. Wounds: A Compendium of Clinical Research and Practice; 14(2):47-57.

[14]. Gardner S.E, Frantz R.A.\& Schmidt F.L (1990). Effect of electrical stimulation on chronic wound healing: a meta-analysis. Wound Repair Regen; 7:495-503.

[15]. Hellewell T.B, Major D.A, Foresman P.A, \&Rodeheaver G.T (1997). A cytotoxicity evaluation of antimicrobial wound cleansers. Wounds;9:15-20.

[16]. Heggers J.P, (1998). Defining infection in chronic wounds: Does it matter? Journal of Wound Care;7(8):452-6.

[17]. Hess C.T (2002). Treatment of pressure Ulcers: Wound Care. 4th ed. Springhouse, Penn.: Springhouse:54-55.

[18]. Ikechukwu E.C (2012), Prevalence and factors associated with healing outcomes of hospital-acquired pressure ulcers among patients with spinal cord injury. Journal of Public Health and Epidemiology Vol. 4(2), pp. 44-47. Available online at http://www.academicjournals.org/JPHE.Accessed on 18th July, 2012.

[19]. Strachan V, (2006), Institute for Clinical Systems Improvement: Pressure ulcer point prevalence survey, State wide report 2006,Victorian Government, 50 Lonsdale Street, Melbourne. Available at: www.health.vic.gov.au/pressureulcers/pdf. Accessed on 18th July, 2012

[20]. D. G. Lam, D. Rastomjee, \& Y. Dynan (2000): Wound irrigation: a simple, reproducible device. Annals of Royal College of Surgeons;82(5):346-7.

[21]. Landi F, Aloe L, Russo A, Cesari M, Onder G, \&Bonini S, (2003) Topical treatment of pressure ulcers with nerve growth factor: a randomized clinical trial. Annals of Internal Medicine;139(8):635-41.

[22]. Lyder,CH, \&Ayello E.A (2007), Chapter 12. Pressure ulcers: a patient safety issue. www.ahrq.gov/qual/nurseshdbk/docs/LyderC_PUPSI.pdf Accessed on 18thJuly, 2012.

[23]. Lyder, et al (2004).Preventing pressure ulcers in Connecticut hospitals using the plan-do-study-act model for quality improvement.Jointt Community Journal Quality Patient Safety;30:205-14.

[24]. Moore Z.E \& Cowman S. (2007). Wound cleansing for pressure ulcers (Review). The Cochrane Collaboration;1:1-16.

[25]. National Pressure Ulcer Advisory Panel (2007).Updated Staging Sysytem.NPUAP Available at http://www.npuap.org/pr2.htm.Accessed on 19th July 2012.

[26]. Olanrewaju A., (2009), Effects of information literacy skills. Available at:http//: www.webpages.uidaho.edu/ mbolin/iss.htm. Accessed 7th April, 2012

[27]. Payne W.G, Ochs D.E, Meltzer D.D, Hill D.P, Mannari R.J, Robson L.E, et al.(2001) Long-term outcome study of growth factortreated pressure ulcers. American Journal of Surgeons;181(1):81-6.

[28]. Posthauer M.E (2005). The role of nutrition in wound care. Advanced Skin and Wound Care; 19:43-52.

[29]. Quirono, J. (2003) Pain in pressure ulcers. Wounds: A Compedium of Clinical Research and Practice;15:381-89.

[30]. Robson M., (1999). Lessons gleaned from the sport of wound watching. Wound Repair Regen;7(1):2-5.

[31]. Rockville, M.D (2006): Agency for Healthcare Research and Quality; AHRQ; National Guideline Clearing House:www.guidelines.gov/search/search.aspx?term=pressure+ulcer/sb3.pdf. Accessed August 19, 2012.

[32]. Rockvill, M.D (2001): Agency for Healthcare Research and Quality. AHRQ Publication No. 01-E058. http://www.ahrq.gov/clinic/ptsafety/chap27.htm. Accessed on 18th July, 2012.

[33]. Rosen, et al. (2005) Organizational change and quality improvement in nursing homes: approaching success. Journal of Healthcare Quality;27(6): 6-14, 21, 44.

[34]. Russo, C. A., \&Elixhauser, A (2006) A. Hospitalizations related to pressure sores, 2003, Healthcare Cost and Utilization Project. Rockville, MD: Agency for Healthcare Research and Quality.

[35]. Royal College of Nursing (2005). The management of pressure ulcers in primary and secondary care. Available at: http://www.nice.org.uk/nicemedia/pdf/CG029fullguideline.pdf. Accessed July 19, 2012.

[36]. Schultz, G., Mozingo, D., Romanelli, M., \& Claxton, K. (2003) Wound bed preparation: a systemic approach to wound management. Wound Repair and Regen;11:1-28.

[37]. Thomas D.R, (2003): The promise of topical growth factors in healing pressure ulcers. Annals of Internal Medicine;139(8):694-95.

[38]. Vermeulen H, van Hattem J.M, Storm- Versloot M.N, \&Ubbink D.T (2007). Topical silver for treating infected wounds (Review). The Cochrane Collaboration;1:1-36.

[39]. World Union of Wound Healing Societies (2006). Principles of best practice: minimizing pain at wound dressing-related procedures, a consensus document. Available at: http://www.wuwhs.org. Accessed 25th July, 2012. 


\section{TABLES}

Table: 1 Socio Demographic Information of Bed-ridden Patients ( $\mathbf{N = 1 2 9 )}$

\begin{tabular}{|c|c|c|c|c|}
\hline \multirow[t]{2}{*}{ Variables } & \multicolumn{2}{|c|}{ Pressure Ulcer present } & \multicolumn{2}{|c|}{ No Pressure Ulcer } \\
\hline & Frequency & Percent $(\%)$ & Frequency & Percent (\%) \\
\hline $\begin{array}{l}\text { SEX } \\
\text { Male } \\
\text { Female }\end{array}$ & $\begin{array}{l}22 \\
2 \\
\end{array}$ & $\begin{array}{l}91.7 \\
8.3\end{array}$ & $\begin{array}{l}74 \\
31 \\
\end{array}$ & $\begin{array}{l}70.5 \\
29.5\end{array}$ \\
\hline $\begin{array}{l}\text { AGE } \\
<10 \\
10-16 \\
17-23 \\
24-30 \\
31-37 \\
38-43 \\
44-50 \\
51-57 \\
58-64 \\
>65\end{array}$ & $\begin{array}{l}0 \\
0 \\
0 \\
2 \\
1 \\
0 \\
2 \\
6 \\
4 \\
9\end{array}$ & $\begin{array}{l}0 \\
0 \\
0 \\
8.3 \\
4.1 \\
0 \\
8.3 \\
25 \\
16.7 \\
37.5\end{array}$ & $\begin{array}{l}5 \\
2 \\
4 \\
11 \\
7 \\
12 \\
14 \\
12 \\
16 \\
22\end{array}$ & $\begin{array}{l}4.7 \\
1.9 \\
3.8 \\
10.5 \\
6.7 \\
11.4 \\
13.3 \\
11.4 \\
15.2 \\
21.0\end{array}$ \\
\hline $\begin{array}{l}\text { WARD } \\
\text { Male medical } \\
\text { Female medical } \\
\text { Male orthopaedic } \\
\text { Female orthopaedic } \\
\text { Neurosurgical }\end{array}$ & $\begin{array}{l}11 \\
2 \\
5 \\
0 \\
6 \\
\end{array}$ & $\begin{array}{l}45.8 \\
8.3 \\
20.8 \\
0 \\
25\end{array}$ & $\begin{array}{l}53 \\
21 \\
9 \\
8 \\
14 \\
\end{array}$ & $\begin{array}{l}50.4 \\
20.0 \\
8.6 \\
7.6 \\
13.3\end{array}$ \\
\hline $\begin{array}{l}\text { DURATION OF STAY } \\
<3 \text { weeks } \\
3-6 \text { weeks } \\
>6 \text { weeks }\end{array}$ & $\begin{array}{l}2 \\
9 \\
13\end{array}$ & $\begin{array}{l}8.3 \\
37.5 \\
54.2\end{array}$ & $\begin{array}{l}63 \\
29 \\
13\end{array}$ & $\begin{array}{l}60.0 \\
27.6 \\
12.3\end{array}$ \\
\hline
\end{tabular}

Table: 2 Socio-demographic of Respondent Nurses ( $\mathrm{N}=51)$

\begin{tabular}{|l|l|l|}
\hline Variables & Frequency & Percent (\%) \\
\hline Sex & & \\
Male & 15 & 29.4 \\
Female & 36 & 70.6 \\
\hline Ward & & \\
Medical orthopaedic & 12 & 23.5 \\
Female orthopaedic & 4 & 7.8 \\
Neurosurgical & 8 & 15.7 \\
Medical ward & 24 & 47.0 \\
Female ward & 3 & 5.9 \\
\hline Rank & & \\
Nursing Officer & 26 & 51.0 \\
Senior Nursing Officer & 14 & 27.5 \\
Principal Nursing Officer & 6 & 11.8 \\
Assistant Chief Nursing Officer & 2 & 3.9 \\
Chief Nursing Officer & 3 & 5.9 \\
\hline Years of Experience & & \\
< 5years & 31 & 60.7 \\
6-11years & 7 & 13.7 \\
12-17years & 6 & 11.8 \\
18-23years & 3 & 5.9 \\
24-29years & 2 & 3.9 \\
> 30years & 2 & 3.9 \\
\hline
\end{tabular}

Table 3 Showing Description and Stages of Pressure Ulcer $(\mathrm{N}=24)$

\begin{tabular}{|l|l|l|}
\hline Variables & Frequency $(\mathbf{N = 2 4})$ & Percent $(\mathbf{\%})$ \\
\hline Location of Pressure Ulcer & & \\
Sacrum & 8 & 33.3 \\
Buttocks & 12 & 50 \\
Heels & 0 & 0 \\
Scapula & 0 & 0 \\
Elbow & 1 & 4.2 \\
Occiput & 0 & 0 \\
Knee & 0 & 0 \\
Ankles & 0 & 0 \\
Others & 3 & 12.5 \\
\hline Number of Ulcers & & \\
Single & 11 & 45.8 \\
Bilateral & 7 & 29.2 \\
Multiple & 6 & 25 \\
\hline
\end{tabular}




\begin{tabular}{|l|l|l|}
\hline Stages of Ulcer & \\
I & 2 & 8.3 \\
II & 5 & 20.8 \\
III & 9 & 37.5 \\
IV & 8 & 33.3 \\
\hline
\end{tabular}

Table: 4 Nurses knowledge on Stage-Based Treatment of Pressure Ulcer

\begin{tabular}{|c|c|c|c|c|c|c|c|c|c|}
\hline \multirow{2}{*}{$\begin{array}{l}\text { Pressure stages } \\
\text { a. Stage one } \\
\text { ulcer care }\end{array}$} & \multirow[t]{2}{*}{ Specific Treatments } & \multicolumn{2}{|c|}{ Correct } & \multicolumn{2}{|c|}{ Undecided } & \multicolumn{2}{|c|}{ Incorrect } & \multicolumn{2}{|c|}{ Total } \\
\hline & & Freq. & $\begin{array}{l}\text { Per } \\
(\%)\end{array}$ & Freq. & $\begin{array}{l}\text { Per } \\
(\%)\end{array}$ & Freq. & $\begin{array}{l}\text { Per } \\
(\%)\end{array}$ & Freq. & $\begin{array}{l}\text { Per } \\
(\%)\end{array}$ \\
\hline & $\begin{array}{l}\text { i Keep off pressure from } \\
\text { sore }\end{array}$ & 41 & 83.6 & 4 & 8.2 & 4 & 8.2 & 49 & 100 \\
\hline & ii Maintain good hygiene & 43 & 87.8 & 5 & 10.2 & 1 & 2 & 49 & 100 \\
\hline & iii Maintain good diet & 48 & 98.0 & 1 & 2.0 & 0 & 0 & 49 & 100 \\
\hline & $\begin{array}{l}\text { iv Apply anti pressure } \\
\text { mattress }\end{array}$ & 45 & 91.8 & 2 & 4.0 & 2 & 4.0 & 49 & 100 \\
\hline & v Apply protective dressing & 40 & 81.6 & 8 & 16.3 & 1 & 2.0 & 49 & 100 \\
\hline & $\begin{array}{l}\text { vi consult Doctor if no } \\
\text { progress }\end{array}$ & 40 & 81.6 & 6 & 12.2 & 3 & 6.1 & 49 & 100 \\
\hline \multirow[t]{3}{*}{$\begin{array}{l}\text { b. Stage two } \\
\text { pressure ulcer }\end{array}$} & $\begin{array}{l}\text { i Follow steps i-iv under } \\
\text { stage I above }\end{array}$ & 26 & 53.1 & 22 & 44.8 & 1 & 2 & 49 & 100 \\
\hline & $\begin{array}{l}\text { ii clean with saline solution } \\
\text { and dry carefully }\end{array}$ & 41 & 83.6 & 6 & 12.2 & 2 & 4.0 & 49 & 100 \\
\hline & $\begin{array}{l}\text { iii check for signs of } \\
\text { infection and inform } \\
\text { Doctor. }\end{array}$ & 43 & 87.8 & 4 & 8.2 & 2 & 4.0 & 49 & 100 \\
\hline \multirow[t]{4}{*}{$\begin{array}{l}\text { c. Stage three } \\
\text { ulcer care }\end{array}$} & $\begin{array}{l}\text { i Follow steps i-iv under } \\
\text { stage one and additional } \\
\text { steps under stage two. }\end{array}$ & 30 & 61.2 & 18 & 36.7 & 1 & 2.0 & 49 & 100 \\
\hline & $\begin{array}{l}\text { ii Apply special cleansing } \\
\text { and debriding agents. }\end{array}$ & 43 & 87.8 & 5 & 10.2 & 1 & 2.0 & 49 & 100 \\
\hline & $\begin{array}{l}\text { iii Apply packing, topical } \\
\text { and systemic antibiotics. }\end{array}$ & 43 & 87.8 & 4 & 10.2 & 2 & 4.0 & 49 & 100 \\
\hline & $\begin{array}{l}\text { iv provide pressure } \\
\text { relieving mattress as } \\
\text { ordered by Doctor. }\end{array}$ & 43 & 87.8 & 4 & 10.2 & 2 & 4.0 & 49 & 100 \\
\hline \multirow[t]{5}{*}{$\begin{array}{l}\text { d. Stage four } \\
\text { ulcer care }\end{array}$} & $\begin{array}{l}\text { i Follow steps i-iv under } \\
\text { stage one and additional } \\
\text { steps under stage two }\end{array}$ & 35 & 71.4 & 14 & 28.5 & 1 & 2.0 & 49 & 100 \\
\hline & $\begin{array}{l}\text { ii Apply special cleansing } \\
\text { and debriding agents }\end{array}$ & 47 & 95.9 & 1 & 2.0 & 1 & 2.0 & 49 & 100 \\
\hline & $\begin{array}{l}\text { iii Apply special packing } \\
\text { agents, topical and systemic } \\
\text { antibiotics }\end{array}$ & 44 & 89.8 & 5 & 10.2 & 0 & 0 & 49 & 100 \\
\hline & $\begin{array}{l}\text { iv Provide pressure } \\
\text { relieving mattress as } \\
\text { ordered by the Doctor }\end{array}$ & 44 & 89.8 & 3 & 6.1 & 2 & 4.0 & 49 & 100 \\
\hline & $\begin{array}{l}\text { v surgery is frequently } \\
\text { required as indicated. }\end{array}$ & 26 & 53.0 & 12 & 24.5 & 11 & 22.4 & 49 & 100 \\
\hline
\end{tabular}

